DANMARKS GEOLOGISKE UNDERSØGELSE

IV. RÆKKE. B D. 4. NR. 6

Geological Survey of Denmark. IV. Series. Vol. 4. No. 6

\title{
Salt Mineralvand fra Danmarks \\ dybere Undergrund
}

Af

Birthe Dinesen

Med 2 tavler

I kommission hos

C. A. REITZELS FORLAG (JØRGEN SANDAL)

KØBENHAVN 1961 
INDHOLD

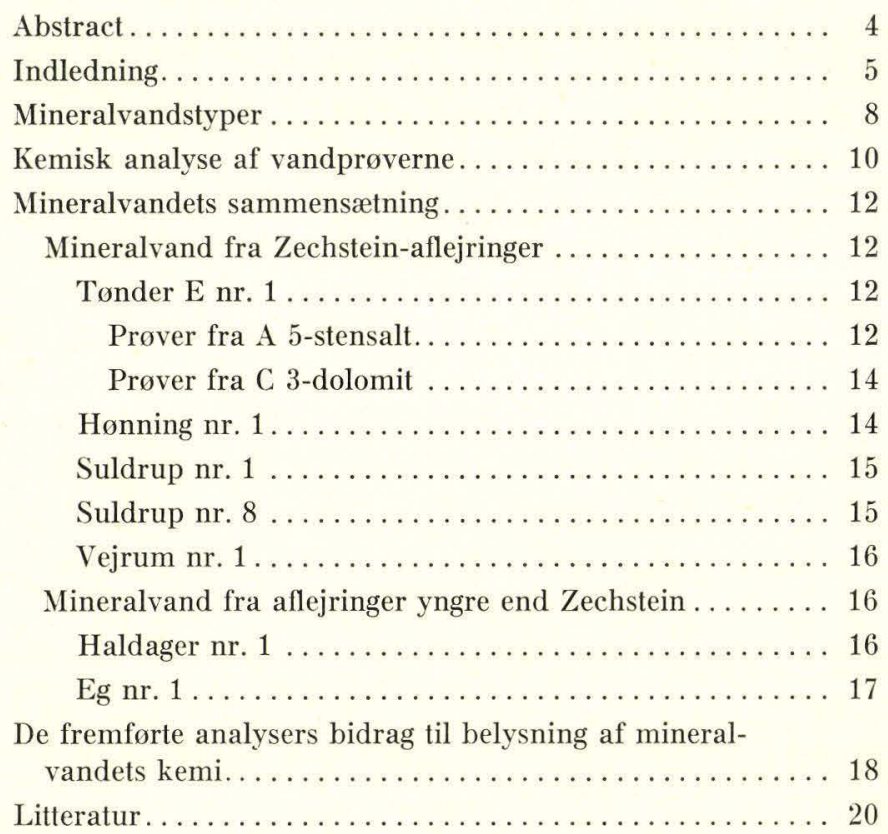

\section{Danmarks}

Biblioteket 


\section{Forord}

Ved den foreliggende behandling af prøver af salt mineralvand har jeg haft lejlighed til at diskutere problemstillingen omkring mineralvandsforekomsterne med statsgeolog $W_{R}$. Christensen og professor, dr. phil. Th. Sorgenfrei.

Tekniske detaljer vedrørende udtagningen af vandprøverne er oplyst af EBBE Christensen.

Tegnearbejdet er udført på D.G.U.'s tegnestue af frk. K. M. OLESEN.

Birthe Dinesen. 


\section{Abstract}

During the drilling operations of Danish American Prospecting Co in Denmark 1946-1959 several mineral water occurences were encountered in the subsurface.

Samples taken from Zechstein deposits show a composition ranging from concentrated almost pure $\mathrm{MgCl}_{2^{-}}$or $\mathrm{CaCl}_{2}$-solutions to solutions more dominated by $\mathrm{NaCl}$. Usually they seem to be migrating solutions which have secondarily reacted with the salt deposits they have penetrated.

Samples from Jurassic and Danian deposits are more diluted NaCl-solutions with a minor content of $\mathrm{CaCl}_{2}$ and $\mathrm{MgCl}_{2}$.

The diluted mineral waters of Denmark are regarded as mixtures of concentrated salt solutions and fresh water.

Uniform composition of diluted mineral waters does not necessitate a uniform composition of the original concentrated salt solutions. It may also be brought about by ion exchange reactions between clays and salt solutions of different composition as e.g. the above mentioned solutions encountered in the Zechstein deposits. 


\section{Indledning}

Formodningen om tilstedeværelsen af saltaflejringer i Danmarks undergrund er ikke af nyere dato. Allerede i 1822 fremsatte Forchнамmer (9) den teori, at visse saltkilder i Vendsyssel skulle skyldes sådanne saltaflejringer - en teori, der dog kunne udelukkes efter Skærumhedeboringen i 1905 (10). Senere - i 1921 - har Nordmann (8) næunt tilstedeværelsen af saltholdige lag som en mulig kilde til saltvandsforekomster ved Kolding, og samme synspunkt er fremfort ved KNuD Hee Andersen's og Hilmar Odum's beskrivelse af saltvandskilden ved Rislev nord for Næstved (3).

Johs. Andersen og H. ØDum (2) foretog i 1930 en gennemgang af de forhåndenværende oplysninger om saltholdigt grundvand og kunne herefter isolere en del lokaliteter, hvor saltvandet hverken kunne opfattes som infiltrerende havvand eller marint residualvand. Det drejede sig om saltvand, der ikke var knyttet til bestemte geologiske lag, men som ofte optrådte i forbindelse med formodede brud i undergrunden. ANDERSEN og ØDum opfattede saltvandet som mineralvand - en vandtype, der f.eks. i Tyskland optræder hyppigt i områder med saltaflejringer - og tog mineralvandsforekomsterne som tegn på, at der måtte findes betydelige saltforekomster i Danmarks undergrund. En gennemgang af analyserne viste, at det overvejende drejede sig om mere eller mindre rene natriumchloridopløsninger, og at ingen af analyserne tydede på tilstedeværelse af kalilejer i undergrunden.

En mere indgående bedømmelse af mineralvandets kemi og geologi blev foretaget af H. Ødum og Wr. Christensen i 1936 (18). Efter denne blev mineralvandet opfattet som en blanding af ferskvand og en stærkt koncentreret saltoplosning, sandsynligvis en ren natriumchloridopløsning. Det blev dog samtidig understreget, at en adskillelse af mineralvand fra de andre saltvandstyper på grundlag af dets kemiske sammensætning ikke var mulig, da mineralvandet sikkert sjældent havde sin oprindelige sammensætning, men oftest var præget af vidtgående reaktioner med de jordlag, vandet var sivet igennem.

Under Danish American Prospecting Co's boringer i Danmark i perioden 1946-1959 blev formodningen om tilstedeværelsen af saltaflejringer i undergrunden bekræftet. Samtidig blev kendskabet til mineralvandets kemi udvidet, idet der under boringerne blev udtaget en del saltvandsprøver, der alle må opfattes som mineralvand. Fra Zechstein-aflejringer foreligger der prover fra det sønderjyske bassin (boringerne Tønder E nr. 1 og Hønning nr. 1) og fra det nordjyske bassin (boring nr. 1 og nr. 8 i Suldrup-horsten og boring nr. 1 i Vejrum-horsten). Fra 


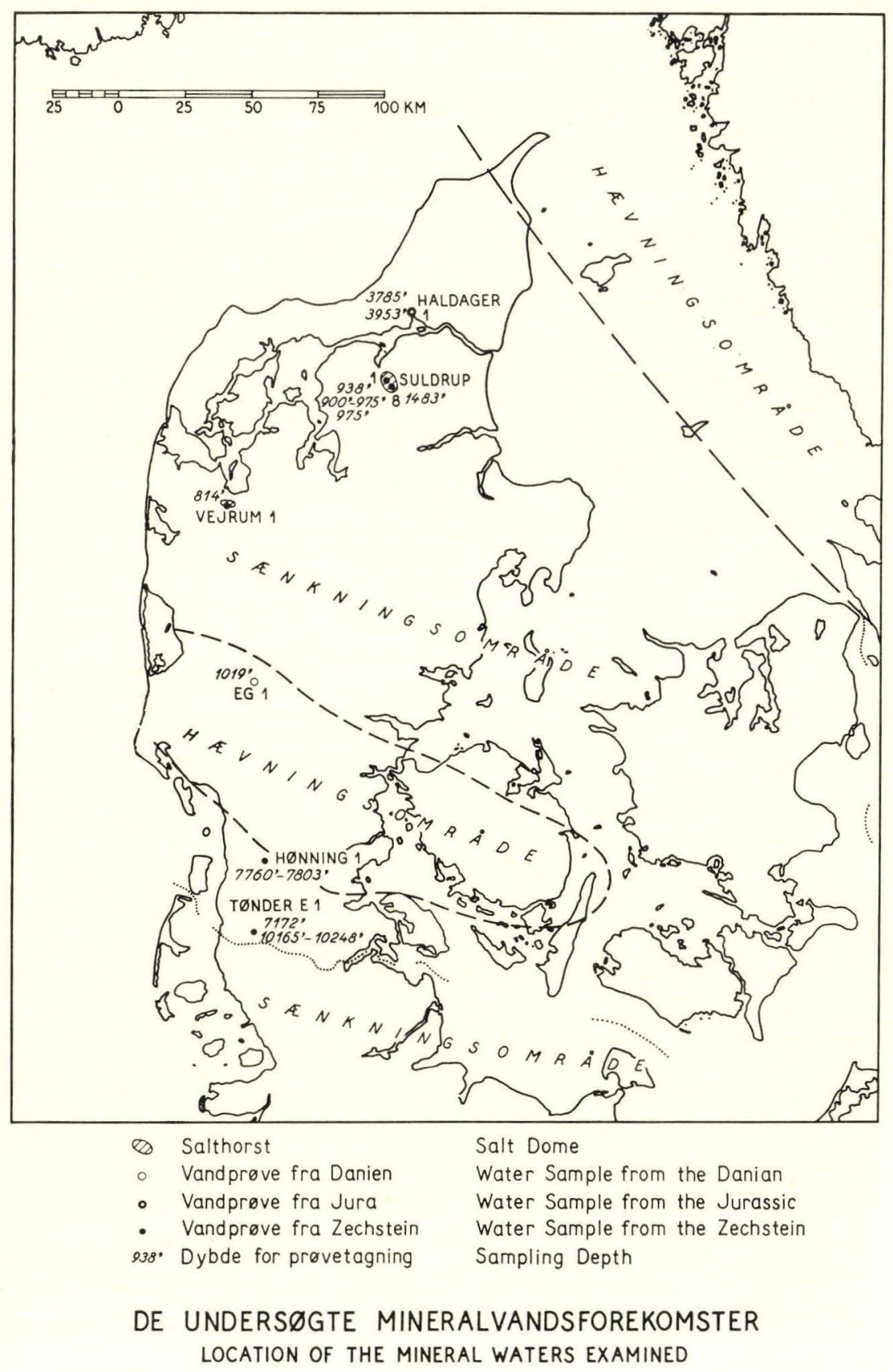

DANMARKS GEOLOGISKE UNDERSøGELSE 1961 BIRTHE DINESEN

Fig. 1. 
yngre aflejringer foreligger der prøver fra boringerne Haldager $\mathrm{nr} .1 \mathrm{og} \mathrm{Eg} \mathrm{nr} .1$. Boringernes beliggenhed fremgår af fig. 1 .

En del af disse prøver blev i 1959 overladt D.G.U. og blev her analyseret i efteråret 1960. Resultatet heraf fremlægges $\mathrm{i}$ det følgende, idet der dog først gives en kort orientering om forskellige mineralvandstyper, væsentligst efter F. LotzE (12). 


\section{Mineralvandstyper}

De saltvandsforekomster, der hyppigt træffes i forbindelse med saltaflejringer, udgøres ikke af een bestemt vandtype, men synes at omfatte saltopløsninger af forskellig oprindelse.

Det saltvand, der ofte optræder sammen med olieforekomster, opfattes af mange som fossilt havvand. Hvor olien optræder i forbindelse med lag i en inddampningsserie, kan der da blive tale om delvis inddampet havvand. Det synes ikke usandsynligt, at der kan træffes saltvand af denne type, idet recente saltaflejringer kan indeholde forbavsende store mængder opløsning.

Som regel synes saltopløsningerne dog at være sekundære, dannet ved genopløsning af udskilte salte $\mathrm{i}$ vand.

Dette vand kan tilføres fra andre aflejringer. Dannelsen af salthorstenes caprock skyldes således, at cirkulerende vand opløser og fjerner de lettere opløselige kalium-, magnium- og natriumsalte, men efterlader tungere opløselige komponenter som anhydrit, dolomit og saltler.

Man er dog af den opfattelse, at de saltopløsninger, der optræder i saltaflejringerne, ofte er opstået i selve saltlagene. De ogede tryk- og temperaturforhold, som saltet blev udsat for, efterhånden som det blev overlejret af yngre aflejringer, skulle bevirke en vandfraspaltning fra krystalvandholdige salte. Således skulle epsomit $\left(\mathrm{MgSO}_{4}, 7 \mathrm{H}_{2} \mathrm{O}\right)$ og gips $\left(\mathrm{CaSO}_{4}, 2 \mathrm{H}_{2} \mathrm{O}\right)$ ved omdannelse til henholdsvis kieserit $\left(\mathrm{MgSO}_{4}, \mathrm{H}_{2} \mathrm{O}\right)$ og anhydrit $\left(\mathrm{CaSO}_{4}\right)$ frigøre betydelige mængder vand, der vil virke opløsende på det omgivende salt.

Uanset saltopløsningens primære eller sekundære karakter vil den under påvirkning af de hydrostatisk og tektonisk betingede trykforhold søge at vandre $\mathrm{i}$ bestemte retninger og vil herved undergå stadige kemiske reaktioner med det omgivende salt, betinget af de tryk- og temperaturforhold, den udsættes for. Dens sammensætning kan derfor være yderst varierende, bestemt af dens fortid. Til belysning heraf tjener foruden indholdet af hovedkomponenterne calcium $\left(\mathrm{Ca}^{++}\right)$, magnium $\left(\mathrm{Mg}^{++}\right)$, natrium $\left(\mathrm{Na}^{+}\right)$, kalium $\left(\mathrm{K}^{+}\right)$, sulfat $\left(\mathrm{SO}_{4}^{--}\right)$og chlorid $\left(\mathrm{Cl}^{-}\right)$ adskillige sporstoffer, f.eks. bromid $\left(\mathrm{Br}^{-}\right)$, bor $(\mathrm{B}+++)$ og ammonium $\left(\mathrm{NH}_{4}{ }^{+}\right)$, hvis forhold under en normal inddampningscyklus kort skal omtales.

Ved inddampning af havvand i et lukket bassin vil der ske en udkrystallisation af saltmineraler i følgende orden: a) calcium-magnium-carbonater, b) calciumsulfat, c) natriumchlorid og d) kalium-magnium-chlorider og -sulfater.

Forholdet $\mathrm{Br}^{-}$: $\mathrm{Cl}^{-}$vil under inddampningen forblive konstant, indtil der sker en udkrystallisation af chlorider. I de udskilte chlorider indgår $\mathrm{Br}^{-}$som isomorf 
substitution for $\mathrm{Cl}^{-}$, og da forholdet $\mathrm{Br}^{-}$: $\mathrm{Cl}^{-}$i krystallerne kun er en brokdel af forholdet i den tilhørende opløsning, vil opløsningens og dermed krystallernes relative $\mathrm{Br}^{-}$-koncentration vokse, efterhånden som udkrystallisationen skrider frem. Krystallernes forhold $\mathrm{Br}^{-}: \mathrm{Cl}^{-}$vil ved en senere genopløsning afspejles i den nye opløsning, og folgelig må sekundært udskilte chlorider have et betydeligt lavere forhold $\mathrm{Br}^{-}: \mathrm{Cl}^{-}$end primært udskilte krystaller af samme type.

Bor udskilles på et ret sent inddampningsstadium og synes koncentreret i kalilagene. De udskilte borater er ret tungtopløselige, og overensstemmende hermed skulle bor væsentligst optræde i primære kalilag og være mindre udbredt i sekundære aflejringer.

Ammonium synes som bor at være koncentreret i kalilag, specielt i lag med sylvin ( $\mathrm{KCl}$ ) og carnallit $\left(\mathrm{KCl}, \mathrm{MgCl}_{2}, 6 \mathrm{H}_{2} \mathrm{O}\right)$. Ifølge Brte og MArcus (6) kan sylvin og carnallit således optage ammoniumchlorid $\left(\mathrm{NH}_{4} \mathrm{Cl}\right)$ under dannelse af blandingskrystaller, og ammoniumindholdet i disse mineraler skulle være op til 100 gange så højt som i mineralerne kieserit $\left(\mathrm{MgSO}_{4}, \mathrm{H}_{2} \mathrm{O}\right)$, polyhalit $\left(\mathrm{K}_{2} \mathrm{SO}_{4}, \mathrm{MgSO}_{4}, 2 \mathrm{CaSO}_{4}\right.$, $\left.2 \mathrm{H}_{2} \mathrm{O}\right)$, tachhydrit $\left(2 \mathrm{MgCl}_{2}, \mathrm{CaCl}_{2}, 12 \mathrm{H}_{2} \mathrm{O}\right)$, stensalt $(\mathrm{NaCl})$ og anhydrit $\left(\mathrm{CaSO}_{4}\right)$. 


\section{Kemisk analyse af vandprøverne}

Vandprøverne indeholdt vekslende mængder slam og jernhydroxyd og måtte filtreres før analyse.

Bestemmelse af "udskilt jern« kunne ikke gennemføres, da en behandling af bundfaldet med saltsyre medførte en betydelig sønderdeling af slammet under frigorelse af jern.

Analysen af de filtrerede vandprøver omfatter bestemmelse af hovedkomponenterne calcium, magnium, natrium, kalium, sulfat og chlorid, af sporstofferne bromid og jodid, af $\mathrm{pH}$ samt en orienterende bestemmelse af bor; ammonium er bestemt kvalitativt i alle prøver og kvantitativt, hvor vandprøvens størrelse har tilladt det.

Bestemmelsen af bromid blev foretaget efter en metode angivet af o'Ans (se H. Biltz og W. Biltz (5), p. 194) til bestemmelse af bromid i kalisalte. Bromid oxyderes med natriumhypochlorit til bromat, idet $\mathrm{pH}$ kontrolleres ved tilsætning af fosfatstødpude, hvorefter overskud af hypochlorit spaltes ved tilsætning af myresyre og natriumformiat. Det dannede bromat reagerer i stærkt sur vædske med tilsat kaliumjodid under frigørelse af jod, der titreres med natriumthiosulfat. Bestemmelsen omfatter også tilstedeværende jodid, der må bestemmes for sig, hvorefter bromidindholdet fås ved subtraktion.

Jodid blev bestemt efter Höfer (se K. HölL (11), p. 117). Metoden er principielt den samme som den, der anvendtes til bromidbestemmelsen; blot foregår reaktionen mellem jodat og tilsat kaliumjodid ved $\mathrm{pH}=3,0$. Ved højere $\mathrm{pH}$ er reaktionen ufuldstændig, og ved lavere $\mathrm{pH}$ fås samtidig reaktion mellem tilstedeværende bromat $\mathrm{og}$ det tilsatte kaliumjodid. Indstillingen af $\mathrm{pH}$ bør derfor foretages nøjagtigt, med $\mathrm{pH}$-meter, især ved så store bromidkoncentrationer som i disse prøver.

Den kvalitative påvisning af bor blev foretaget kolorimetrisk efter ALEKSANDRov og Cviк (1) med en svovlsur karminopløsning. Borbestemmelsen blev foretaget ved titrering af mannitolborsyre efter fjernelse af jern og aluminium og udkogning af kulsyre i sur vædske. Borsyren frigøres ved indstilling af pH på methyloranges omslagspunkt, og efter tilsætning af mannitol titreres mannitolborsyren med natriumhydroxyd til fenolftaleins omslagspunkt. Fra det fundne baseforbrug trækkes den basemængde, der anvendes ved en tilsvarende titrering af samme mængde destilleret vand.

Kalium og natrium blev bestemt flammefotometrisk. De i tavle I angivne værdier for natrium er beregnet som differens mellem anioner og kationer; de flammefotometrisk bestemte værdier er anført i parentes.

Der blev ikke foretaget bestemmelse af bicarbonat. Den normale titrering med 
saltsyre synes ikke at kunne anvendes ved tilstedeværelse af bor, da tilsætning af saltsyre foruden omdannelse af bicarbonat til kulsyre også vil medføre omdannelse af tilstedeværende borater til borsyre.

Prøvernes indhold af "opløst jern« blev ikke bestemt. Det repræsenterer næpғe det oprindelige jernindhold, da flere års henstand i flaske sandsynligvis har medfort en vis iltning og udfældning af jernet. 


\section{Mineralvandets sammensætning}

Resultatet af de udforte analyser fremgår af tavle I, der desuden omfatter visse analyser, som D.A.P.Co har ladet udføre. Prøvernes sammensætning er grafisk fremstillet i tavle II, hvor der samtidig er indtegnet enkelte mineralvandsanalyser efter H. Odem og Wr. Christensen (18) samt en analyse af havvand efter K. Rankama og Th. Sahama (14). Provernes dybdeangivelse i' er regnet fra boretårnets rotationsbord; i teksten er de tilsvarende koter angivet i parentes.

\section{Mineralvand fra Zechstein -aflejringer.}

\section{Tonder E nr. 1.}

Prover fra A 5 - stensalt. I alt foreligger der 3 analyser af vandprøver fra det ovre afsnit af saltaflejringerne, svagt kaliholdigt A 5-stensalt, overlejret af $6 \mathrm{~m}$ A 8-anhydrit. Saltets bogstav- og talbetegnelse refererer til en inddeling af den gennemborede saltserie, foretaget af TH. Sorgenfrei $(15,16)$; bogstavet er en cyklusbetegnelse, og tallet angiver salttypen inden for den enkelte cyklus. Prøverne er alle udtaget ved jordoverfladen, efter at et kraftigt gas- $\mathrm{og}$ saltvandsudbrud var begyndt, da man nåede stensaltet d. 31/8 1951. Prøverne 1 og 2 - analyseret af henholdsvis D.G.U. og Qvist's laboratorium - blev udtaget d. 4/9, 4 dage efter udbruddets begyndelse, da boringens dybde var $7172^{\prime}(\div 2172,6 \mathrm{~m})$; prøve 3 analyseret af Gulf Research \& Development Co., Pittsburgh - blev forst udtaget d. $19 / 9$, da boringens dybde var $7197^{\prime}(\div 2180,2 \mathrm{~m})$.

Da proverne ikke er udtaget samtidig, kan det ikke forventes, at de er fuldstændig identiske. Analyseresultaterne tyder dog på, at der er tale om en mineralvandsforekomst af ret konstant sammensætning.

Et ringe sulfatindhold som angivet i prøverne 2 og 3 kan ikke udelukkes i prove 1 ; en kvalitativ prøve viste således en ganske svag positiv reaktion efter et døgns henstand. Men det er et sporgsmål, hvor stor vægt der kan tillægges de opgivne værdier, hvis de er bestemt efter den normale gravimetriske metode. En sådan bestemmelse vil nemlig kræve en så stor prøve, at den forudgående udskillelse af kiselsyre kan blive vanskelig og ufuldstændig på grund af de meget store mængder udskilt salt, således at opløst kiselsyre kan rives med ved sulfatfældningen.

Den ret store forskel i de angivne jodværdier skyldes måske en reel forskel i prøvernes jodindhold, men det kan ikke udelukkes, at den skyldes analysemetoderne. En del af det tilstedeværende jod optræder muligvis i en form, der bestemmes 
ved den af Gulf anvendte metode, men ikke ved den på D.G.U. anvendte. Hvis de to bestemmelser er udført efter samme metode, kan den af Gulf angivne ret høje værdi skyldes, at den endelige titrering er udført ved et lidt for lavt $\mathrm{pH}$, hvilket som nævnt p.10 ved et så stort bromoverskud som $\mathrm{i}$ disse prøver vil medføre, at bromat deltager i reaktionen og derved giver for høje jodværdier. Den på D.G.U. bestemte værdi er kontrolleret med tilfredsstillende resultat ved analyse af vandprøven efter tilsætning af en kendt mængde jodidstandard.

Prøverne repræsenterer en magniumchloridopløsning med et vist indhold af kaliumchlorid og calciumchlorid, mens indholdet af natriumchlorid er ret ringe. Indholdet af både bor, bromid og ammonium er betydeligt; forholdet $\mathrm{Br}^{-}$: $\mathrm{Cl}^{-}$ er således 6 gange så højt som i havvand.

Den kemiske sammensætning tyder på, at der enten er tale om en primær, stærkt inddampet moderlud eller en sekundær opløsning præget af kontakt med primære carnallitholdige kalilag. Opløsningens bemærkelsesværdigt lave $\mathrm{pH}$ kan tildels skyldes, at der efter proveudtagningen er sket en betydelig oxydation og udfældning af jern efter ligningen $\mathrm{Fe}^{++}+3 \mathrm{H}_{2} \mathrm{O} \underset{\leftarrow}{\longrightarrow} \mathrm{Fe}(\mathrm{OH})_{3}+3 \mathrm{H}^{+}+\mathrm{e}^{-}$; men der er også mulighed for, at det kan tages som et tegn på, at opløsningen er primær moderlud. Ifølge U. MARr (13) skulle en stærkt inddampet moderlud således kunne fă et pH på 4-5 på grund af det kulsyreoverskud, der opstår ved carbonatudfældningen, hvis det antages, at kulsyreoverskuddet ikke afgives kontinuerligt til atmosfæren under inddampningen. Spørgsmålet om oplosningens primære eller sekundære karakter må dog indtil videre stå åbent; måske kan en undersøgelse af forskellige kalisaltes bromindhold bringe losningen nærmere.

Oplosningens indhold af calciumchlorid tyder på reaktioner mellem magniumchloridopløsningen og calciumholdige lag - reaktioner, der f.eks. vil finde sted, hvis oplosningen under vandring trænger gennem lag af anhydrit eller dolomit (se U. Marr (13) og U. Storck (17)).

Den kendsgerning, at opløsningen står under et tryk, der nærmer sig bjergartstrykket, taler imidlertid for, at opløsningen ikke har vandret over større strækninger. I så fald kan calciumchloridindholdet skyldes kontakten med det overliggende anhydritlag, og det er da nærliggende at opfatte opløsningen som udtryk for et stærkt fremskredet inddampningsstadium i A-cyklen.

Saltopløsningens høje bromindhold rejser spørgsmålet, om den kan betragtes som et velegnet udgangsmateriale for en bromudvinding.

Brom er et meget anvendt stof, både inden for den uorganiske og den organiske industri. En del brom bruges til fremstilling af bromider; alkalibromider anvendes f.eks. ved fremstilling af farvestoffer (eosin), bromoform og ethylendibromid, der tilsættes benzin sammen med antibankestoffer som f.eks. tetraethylbly.

Verdensmarkedet for brom synes for tiden at være ret stabilt; men udviklingen af en række hjemlige industrier i forbindelse med de planlagte olieraffinaderier muliggør en oget lokal efterspørgsel.

Råmaterialet for bromudvindingen udgøres i Tyskland enten af restluden fra carnallitoparbejdningen eller af en del af det cirkulerende oplosende saltrandssystem ved oparbejdningen af hårdtsalt og sylvinit. Fremstillingen foregår som regel efter folgende princip: Efter forvarmning til ca. $80^{\circ}$ behandles saltopløsningen med chlorgas og vanddamp efter modstromsprincippet i en kolonne; herved fri- 
gøres brom, der samtidig afdestilleres. Bromdampene kondenseres i kølere, og kondensatet renses for opløst chlor ved en påfølgende opvarmning til $50-55^{\circ} \mathrm{C}$.

Ifølge B.I.O.S. Final Report No 1616: "The Winning and Refining of Potash Minerals in the Western Zones of Germany" part II skulle bromfremstillingen være rentabel, når saltopløsningernes bromindhold ikke er under 1,2 g Br/l, og anlæggenes kapacitet skulle være af størrelsesordenen 10-20 $\mathrm{m}^{3}$ saltopløsning/time. Den her omtalte saltopløsning indeholder ca. $6 \mathrm{~g} \mathrm{Br} / \mathrm{l}$, dvs. 5 gange så meget, og må derfor betragtes som absolut velegnet som råmateriale. Spørgsmålet er blot, om det vil være muligt at skaffe tilstrækkelige mængder til at holde en produktion i gang. Til trods for, at opløsningen står under et betydeligt tryk - ved jordoverfladen var trykket $=141 \mathrm{~kg} / \mathrm{cm}^{2}-$ var kapaciteten nemlig ret ringe, kun ca. $0.7 \mathrm{~m}^{3} /$ time. Før kapaciteten bliver nærmere undersøgt, kan muligheden for en bromudvinding ikke bedommes.

Prøver fra C 3-dolomit. Fra den svagt olieholdige C 3-dolomit foreligger der prøver fra dybdeintervallet $10165^{\prime}-10248^{\prime}(\div 3084,9 \mathrm{~m}-\div 3110,2 \mathrm{~m})$, mærket swab sample 1-4, udtaget d. $9 / 3$ 1952. For nr. 4 foreligger der desuden resultat af en analyse, som D.A.P.Co har ladet udføre. Swab sample er en betegnelse for prøver af formationsvædske, der er udtaget ved pumpning gennem et særskilt rørsystem. Før pumpningen isoleres det dybdeinterval, hvorfra der ønskes prøver, enten ved hjælp af pakninger eller ved cementering af borehullet $\mathrm{og}$ påfølgende perforering af cementen i det pågældende dybdeinterval.

Prøverne er stærkt brunligt farvede og virker skummende, sandsynligvis på grund af et ikke ubetydeligt olieindhold. På grund heraf har der hverken kunnet foretages en kvalitativ eller kvantitativ bestemmelse af bor. Bortset fra værdierne for bromid og jodid viser analyserne udført på D.G.U. ret god overensstemmelse med den for D.A.P.Co foretagne analyse. I modsætning til prøverne fra A 5-stensaltet er de på D.G.U. bestemte værdier for både bromid og jodid betydeligt højere end de for D.A.P.Co bestemte. Den meget store uoverensstemmelse skyldes måske prøvernes olieindhold, men da analysemetoden for de for D.A.P.Co bestemte værdier ikke kendes, kan der ikke tages stilling til, hvilke resultater der bør tillægges størst værdi.

Prøvernes kemiske sammensætning er ret ensartet og må derfor anses for repræsentativ for formationsvædsken. Der er tale om en natriumchloridopløsning med samme procentiske indhold af calciumchlorid som prøverne fra A 5-stensaltet, men med et betydeligt ringere indhold af kaliumchlorid og især af magniumchlorid. Forholdet $\mathrm{Br}^{-}: \mathrm{Cl}^{-}$er lavere end $\mathrm{i}$ havvand.

Opløsningens sammensætning afviger betydeligt fra den før omtalte saltopløsning fra A 5-stensaltet. Dens indhold af calciumchlorid, det ubetydelige sulfatindhold og det ret lave forhold $\mathrm{Br}^{-}: \mathrm{Cl}^{-}$tyder på, at der ikke er tale om en til dolomitten svarende primær moderlud. Det synes snarere at dreje sig om en vandret opløsning - primær eller sekundær - der er præget af et mindre fremskredet inddampningsstadium end oplosningen fra A 5 -stensaltet.

Honning $n r .1$.

Under Hønning-boringen blev der d. 1/10 1958 udtaget en prøve af formationsvædske fra intervallet $7760^{\prime}-7803^{\prime}(\div 2333,0 \mathrm{~m}-\div 2347,0 \mathrm{~m})$ (sandsynligvis som 
Halliburton test, se p. 16) fra svagt olieholdig dolomit, svarende til cyklus D i Tønderboringerne. Prøven indeholdt ikke olie, men bestod af svagt gasholdigt, mudret saltvand, hvoraf der blev udtaget en prøve til kemisk analyse.

Provens store mudderindhold tyder på opblanding med boremudder, og det er tvivlsomt, om opløsningen repræsenterer rent formationsvand. En forurening med kemikalier fra boremudderet vil imidlertid næppe øge prøvens indhold af kaliumog magniumsalte, da mudderet $\mathrm{i}$ dette interval ifølge "Drillers Log « kun var tilsat natriumchlorid og bariumsulfat. Kun ved specielle kaliboringer tilsættes mudderet ofte kaliumchlorid og magniumchlorid.

Prøven består af en natriumchloridopløsning med et procentisk kaliumchloridindhold af samme størrelsesorden som prøven fra A 5-stensaltet i Tønder-boringen, men med et mindre indhold af magniumchlorid og calciumchlorid. På grund af ringe prøvemængde blev der kun foretaget bestemmelse af $\mathrm{Br}^{-}+\mathrm{J}^{-}$, hvorfor forholdet $\mathrm{Br}^{-}: \mathrm{Cl}^{-}$ikke figurerer i tavle II. Da jodidindholdet normalt er ubetydeligt i forhold til bromidindholdet, skønnes det dog, at forholdet $\mathrm{Br}^{-}: \mathrm{Cl}^{-}$må være ca. 3 gange så stort som i havvand.

Opløsningen repræsenterer et inddampningsstadium efter udskillelse af væsentlige mængder stensalt. Den kan ikke være en primær moderlud svarende til dolomitten, men må have vandret og være præget af kontakt med andre lag. Da det ikke kan afgøres, hvorfra opløsningen stammer, og hvilke lag den har passeret, kan den næppe opfattes som udtryk for et ret fremskredet inddampningsstadium i D-cyklen, der i de udforte boringer kun er udviklet til dolomit- og anhydritfasen.

\section{Suldrup nr. 1}

Under boring nr. 1 i Suldrup-horsten blev der kærneboret med meget ringe kærneprocent $\mathrm{i}$ intervallet $897^{\prime}-998^{\prime}(\div 243,0 \mathrm{~m}-\div 273,8 \mathrm{~m})$. Kærnerne bestod af stensalt med kolossale opløsningsgruber, og for at få afgjort, om der var tale om et kaliholdigt lag, blev der d. 17/4 1947 udtaget 3 bailer samples i intervallet $900^{\prime}-975^{\prime}(\div 243,9 \mathrm{~m}-\div 266,8 \mathrm{~m})$. En bailer sample udtages med en beholder med bundventil, og den udgores af en del af den vædske, der står i borehullet.

De 3 prøver er af ensartet sammensætning. De udgøres af en stensaltopløsning med et kun ubetydeligt kaliumindhold, og deres sammensætning tyder ikke på, at den gennemborede zone kan være særlig kaliførende.

\section{Suldrup nr. 8 .}

Under boringen Suldrup nr. 8 blev der d. 8/7 1948 udtaget vandprøver i forbindelse med et udbrud af artesisk saltvand, der indtraf, da boringen i en dybde af $1483^{\prime}(\div 408,1 \mathrm{~m})$ nåede toppen af et ca. $30 \mathrm{~m}$ mægtigt lag af dolomit og anhydrit, overlejret af stensalt og underlejret af anhydrit og stensalt.

Foruden resultatet af den på D.G.U. foretagne analyse foreligger der resultat af en analyse, som D.A.P. Co har ladet udfore.

Prøven består af en calciumchloridopløsning med et vist indhold af magniumchlorid men et kun ubetydeligt indhold af kaliumchlorid; den er som prøven fra A 5-stensaltet i boringen Tønder E nr. 1 karakteriseret red et ret højt indhold af bromid, bor og ammonium samt et bemærkelsesværdigt lavt $\mathrm{pH}$.

Det drejer sig sandsynligvis om en oprindelig kaliumholdig magniumchloridoplosning, der ved senere omfattende reaktioner med anhydrit og dolomit er om- 
dannet til en opløsning, der er domineret af calciumchlorid. Opløsningen er præget af et stærkt fremskredet inddampningsstadium, der måske står i forbindelse med de konstaterede kaliforekomster i Suldrup-horsten. Men hvilken cyklus dette inddampningsstadium skal henføres til, står endnu hen i det uvisse.

\section{Vejrum nr. 1.}

Fra boring nr. 1 i Vejrum-horsten foreligger der en vandprøve udtaget $\mathrm{i}$ juni 1946 som bailer sample i stensalt $i$ en dybde af $814^{\prime}(\div 209,7 \mathrm{~m})$, ca. $2 \frac{1}{2} 2 \mathrm{~m}$ under cap-rock,

Prøven er en natriumchloridopløsning med et ringe indhold af calciumsulfat og kaliumchlorid. Forholdet $\mathrm{Br}^{-}: \mathrm{Cl}^{-}$er kun ca. ${ }^{1 / 12}$ af det tilsvarende forhold for havvand, og der har ikke kunnet påvises bor eller ammonium. Alt tyder på, at saltvandet er dannet ved opløsning af det gennemborede stensalt.

\section{Mineralvand fra aflejringer yngre end Zechstein.}

\section{Haldager $\mathrm{nr} .1$.}

Fra boringen Haldager nr. 1 foreligger der prover udtaget d. 25/11 og 27/11 1950 som Halliburton tests i dybderne $3785^{\prime}(\div 1148,5 \mathrm{~m})$ og $3953^{\prime}(\div 1199,7 \mathrm{~m})$ i Jura-aflejringer. Ved en Halliburton test lader man formationsvand fra et bestemt interval - begrænset af pakninger og boringens bund - stige op i borestammen, hvorefter der under røroptagningen kan udtages prøver fra forskellige afsnit af denne vædskesøjle. Prøver udtaget i søjlens overste afsnit vil oftest være forurenede, men vil i højere grad få karakter af rent formationsvand, jo nærmere bunden de udtages.

For begge dybder er saltholdigheden størst i den prøve, der er udtaget nærmest boringens bund; men om denne udgøres af rent formationsvand, eller om den stadig er fortyndet, kan ikke afgøres. Prøvernes procentiske sammensætning er imidlertid ensartet, uafhængig af saltholdigheden, og må derfor opfattes som udtryk for formationsvandets sammensætning.

Prøverne består af en natriumchloridopløsning med et vist indhold af calciumchlorid, men et kun ringe indhold af magniumchlorid og kaliumchlorid. Forholdet $\mathrm{Br}^{-}$: $\mathrm{Cl}^{-}$er af samme størrelsesorden som i havvand.

Opløsningen må opfattes som en blanding af ferskvand og en mættet saltopløsning, sandsynligvis fra Zechstein- eller aride Trias-aflejringer. Det ret høje bromindhold kan tyde på, at denne saltopløsning ikke har været en rent sekundær stensaltopløsning af samme type som prøven fra Vejrum-horsten. Forholdet $\mathrm{Br}^{-}: \mathrm{Cl}^{-}$ er således 14 gange så stort som i Vejrum-prøven, og en så stor ændring i stensaltets bromindhold før en begyndende kaliudskillelse er usandsynlig.

Der kan måske være tale om fossilt havvand, inddampet til begyndende stensaltudskillelse, men på grund af de talrige muligheder for ændringer i den kemiske sammensætning under saltopløsningens vandring kan der kun gisnes om dens oprindelige karakter.

Dels vil saltopløsningen stadig søge at opnå kemisk ligevægt med de jordlag, den trænger igennem, og dels er det vanskeligt at bedomme fortyndingens indflydelse på forholdet $\mathrm{Br}^{-}: \mathrm{Cl}^{-}$. Tilsyneladende ændrer en fortynding til det dobbelte ikke forholdet væsentligt, men før der er foretaget undersøgelse af ferskvandets bromindhold, er en nærmere bedømmelse af fortyndingseffekten næppe mulig. 


\section{Eg nr. 1.}

Under boringen Eg nr. 1 blev der d. 3/1 1951 udtaget en vandprove i forbindelse med et kraftigt udbrud af artesisk saltvand, der indtraf, da boringen i en dybde af 1019' $(\div 310,6 \mathrm{~m})$ nåede grænsen Eocæn-Danien.

Prøven består af en natriumchloridopløsning med et vist indhold af calciumchlorid og magniumchlorid, men et kun ringe indhold af kaliumchlorid. Forholdet $\mathrm{Br}^{-}: \mathrm{Cl}^{-}$er af samme størrelsesorden som i havvand.

Opløsningen minder påfaldende om den mindst salte af Haldager-prøverne. Den må som Haldager-opløsningen opfattes som en blanding af ferskvand og en stærkt koncentreret saltopløsning. Eg-boringen er placeret i det midtjyske hævningsområde, hvor der ikke hidtil er konstateret Zechstein-aflejringer. Det er derfor mest nærliggende at antage, at saltopløsningen stammer fra aride Trias-aflejringer, hvis tilstedeværelse er påvist i den nærliggende Grindsted-boring. Dog kan det ikke udelukkes, at opløsningen er tilvandret fra det nord-eller sydjyske Zechstein-bassin. 


\section{De fremførte analysers bidrag til belysning af mineralvandets kemi}

Som næunt i indledningen p. 5 opfattede H. Ødum og Wr. Christensen mineralvand som en blanding af ferskvand og en stærkt koncentreret saltopløsning. Den kendsgerning, at de mest salte mineralvandsprøver var af ret ensartet sammensætning og overvejende bestod af en natriumchloridopløsning med et vist indhold af calciumchlorid og magniumchlorid - se f.eks. analyserne fra Sønderborg, Langbrogård, Tullebølle og Gedser, anført i tavle II - forte til den antagelse, at den oprindelige saltopløsning måtte være en ret ren natriumchloridopløsning, og at prøvernes indhold af calciumchlorid og magniumchlorid måtte skyldes regeneration ved ionbytningsreaktioner efter ligningen:

$$
\mathrm{Na}_{2} \mathrm{Z}+\mathrm{Ca}^{++} \rightleftarrows \mathrm{CaZ}+2 \mathrm{Na}^{+} \text {, læst fra højre } \bmod \text { venstre. }
$$

De her fremførte mineralvandsanalyser viser imidlertid, at de koncentrerede saltopløsninger, der optræder i forbindelse med saltaflejringer, ikke udelukkende udgøres af natriumchloridopløsninger, men tværtimod kan have en yderst varierende sammensætning.

I selve Zechstein-lagene er der således truffet såvel næsten rene magniumchlorideller calciumchloridopløsninger som mere natriumchloridprægede opløsninger.

De mineralvandsprøver, der stammer fra Jura og Danien, viser en mere ensartet sammensætning, der med hensyn til hovedkomponenterne kan minde om de mineralvandsprøver, der omtales af H. ØDum og WR. Christensen. De sparsomme oplysninger, der foreligger om disse prøvers indhold af sporstoffer, f.eks. ammonium og bromid (bromid og forholdet $\mathrm{Br}^{-}$: $\mathrm{Cl}^{-}$er i forbindelse med den foreliggende undersøgelse bestemt i en opbevaret delprøve fra Langbrogård), kan dog tyde på, at der ikke er tale om saltopløsninger af samme oprindelse.

Bromidværdierne i prøverne fra Haldager og Eg synes som nævnt p. 16-17 at kunne udelukke, at dette saltvand oprindeligt har været en rent sekundær natriumchloridopløsning. I Langbrogård-prøven er forholdet $\mathrm{Br}^{-}$: $\mathrm{Cl}-$ derimod kun halvt så stort som i prøverne fra Haldager og Eg, og det kan ikke udelukkes, at det her drejer sig om en stensaltopløsning, der under vandring gennem jordlagene er fortyndet $\mathrm{og}$ regenereret efter ovennæunte ligning. Da lignende oplysninger ikke foreligger for prøverne fra Sønderborg, Tullebølle og Gedser, kan disses oprindelse ikke diskuteres nærmere; men prøvernes sammensætning med hensyn til hoved- 
komponenterne viser så god overensstemmelse med Langbrogård-prøven, at intet taler imod, at det drejer sig om saltopløsninger af samme oprindelse.

For en del lokaliteter må H. ØDum og WR. Christensen's opfattelse af mineralvandet som en fortyndet og regenereret natriumchloridopløsning således stadig anses for sandsynlig.

Konstateringen af de stærkt koncentrerede calciumchlorid- og magniumchloridopløsninger i Zechstein-aflejringerne medfører imidlertid, at sådanne opløsninger også må tages i betragtning som mulige stamopløsninger for det fortyndede mineralvand. Dette kan udmærket opfattes som fortyndede opløsninger af calcium- eller magniumchlorid, der ved ionbytningsreaktioner med marint ler har fået ombyttet størsteparten af calcium og magnium, eventuelt også kalium med natrium.

I forbindelse med behandlingen af de i Danmark konstaterede forekomster af salt mineralvand er det nærliggende at omtale de saltopløsninger, der blev truffet under dybdeboringer i Skåne i perioden 1944-1947, f.eks. i boringen Höllviken II (G. Assarsson (4) og F. Brotzen (7)).

Under denne boring blev der i dybdeintervallet 1200-1687 m udtaget prøver af stærkt calciumchloridholdige natriumchloridopløsninger fra nedre Kridt og øvre Trias (til og med øvre Keuper), mens der i 1855 m dybde blev udtaget en næsten ren natriumchloridopløsning fra det nederste afsnit af Muschelkalk.

Opløsningerne fra intervallet 1200-1687 m viser trods en med dybden stigende saltholdighed (76100-108900 mg Cl-/l) en ret ensartet procentisk sammensætning med $33-37 \%$ calciumchlorid og 2-3\% magniumchlorid. I de prøver, hvor bromid er bestemt, er forholdet $\mathrm{Br}^{-}: \mathrm{Cl}^{-}$ca. 11/2 gang så højt som i havvand. Opløsninger af denne type er også truffet i boringerne Höllviken I og Trelleborg. Prøvernes ret høje forhold $\mathrm{Br}^{-}$: $\mathrm{Cl}-$ tyder på, at opløsningen har været inddampet så stærkt, at der er sket en ikke ubetydelig udskillelse af stensalt, og det store indhold af calciumchlorid må være resultat af omfattende reaktioner med calciumholdige udskillelser, f. eks. kalk, dolomit og anhydrit. Opløsninger af samme type er ikke truffet i Danmark. Den danske mineralvandsforekomst, der ligner denne Höllviken-opløsning mest, er Haldager-opløsningen, der blev udtaget i Jura-aflejringer; men denne cr ikke præget af så kraftig inddampning og heller ikke af så omfattende reaktioner med calciumholdige lag som Höllviken-opløsningen.

Opløsningen fra $1855 \mathrm{~m}$ dybde er af anden type. Det er en natriumchloridoplosning med ca. $1 \%$ calciumsulfat, $1 \%$ magniumchlorid og $1 / 2 \%$ kaliumchlorid. Forholdet $\mathrm{Br}^{-}: \mathrm{Cl}^{-}$er kun ca. ${ }^{1 / 14}$ af det tilsvarende forhold i havvand. Opløsningen minder påfaldende om den bailer sample, der blev udtaget i stensalt $\mathrm{i}$ Vejrum-horsten, og er sandsynligvis fremkommet ved genopløsning af udskilt stensalt.

Som det vil fremgå af denne gennemgang af forskellige mineralvandsforekomster, kan mineralvandet have en yderst varierende sammensætning. Opløsninger af forskellig type optræder ikke blot på forskellige lokaliteter, men kan træffes i forskellig dybde i samme boring. En vurdering af mineralvandets kemiske sammensætning bør derfor foretages under nøje hensyntagen til det geokemiske miljø, selv om en eentydig bedømmelse af mineralvandets oprindelse næppe er mulig for øjeblikket. 


\section{Litteratur}

D.G.U. = Danmarks Geologiske Undersøgelse. - København

D.G.F. $=$ Meddelelser fra Dansk Geologisk Forening. - Kobenhavn.

S.G. U. = Sveriges Geologiska Undersökning. - Stockholm.

1. Aleksandrov, G. V. und CviK, S. M., 1953: Zur colorimetrischen Borbestimmung in natürlichen Kaliumsalzen. - Z. anal. Chem. Bd. 140, p. 155. - München.

2. Andersen, Johs. og Ødum, H., 1930: Om Forekomsten af saltførende Aflejringer i Danmarks Undergrund. - D.G.U. II. Rk. Nr. 52.

3. Andersen, K. Hee og Ødum, H., 1923: En Salt-Flora i Slagsmose ved Rislev. Bot. Tidsskr. Bd. 38, p. 57. - København.

4. Assarsson, G., 1949: On the Winning of Salt from the Brines in Southern Sweden.S.G.U. Ser. C, nr. 501.

5. Biltz, H. und Biltz, W., 1947: Ausführung quantitativer Analysen. - Zürich.

6. Biltz, W. und Marcus, E., 1911: Uther Ammoniumcarnallit. - Z. anorg. Chemie. Bd. 71, p. 166. - Hamburg.

7. Bвотzen, F., 1950: De geologiska resultaten från borrningarna vid Höllviken. Del II. Undre Kritan och Trias. - S.G.U. Ser. C, nr. 505.

8. Eliassen, P., Brandorff, I. O. og Nordmann, V., 1921: Det gamle Saltværk ved Kolding. - Vejle Amts Aarbøger.

9. Forchнамmer, G. 1822: Om Danmarks geognostiske Forhold. - Tidsskr. for Naturvidensk. I. - Kobenhavn.

10. Jessen, A. m.fl., 1910: Fn Boring gennem de kvartære Lag ved Skærumhede. D.G.U. II. Rk. Nr. 25.

11. HöLl, K., 1958: Untersuchung, Beurteilung, Aufbereitung von Wasser. - Berlin.

12. Lotze, F., 1957: Steinsalz und Kalisalze. I. Teil. - Berlin.

13. Marr, Ulrike, 1958: Die Bildung des Stassfurt-Flözes unter Berücksichtigung geochemischer Untersuchungen (II). - Mineralsalze ozeanischen Ursprungs. - Freiberger Forschungshefte A 123. - Berlin.

14. Rankama, K. and Sahama, Th. G., 1949: Geochemistry. - Chicago, Helsinki.

15. Sorgenfrei, Th., 1952: The Upper Permian Zechstein Formation in Tønder No. 1. Deep Test Interval 7065'-10248'. - (Intern rapport.)

16. - 1957: Perm-systemet i det sydlige Danmark. - D.G.F. Bd. 13, p. 263

17. Sтовск, U., 1955: Die Entstehung der Vertaubungen in den Kalisalzlagern im Zusammenhang mit regelmässigen Begleiterscheinungen auf dem Kaliwerk Königshall-Hindenburg. - Z. Deutsch. Geol. Ges. Jahrg. 1953. Bd. 105, 4. Teil, p. 685. - Hannover.

18. Ødum, H. og Christensen, Wr., 1936: Danske Grundvandstyper og deres geologiske Optræden. - D.G.U. III. Rk. Nr. 26. 


\begin{tabular}{|c|c|c|c|c|c|c|c|c|c|c|c|c|c|c|c|c|c|c|c|}
\hline \multicolumn{5}{|c|}{ D. G. U. IV. Rk. Bd. 4. Nr. 6.} & \multicolumn{14}{|c|}{ Analyseresultater - Analytiteal Results. } & Tavie I \\
\hline $\begin{array}{c}\text { D.G., U. U. } \\
\text { Arkiv niv. }\end{array}$ & Lokalititet & $\begin{array}{l}\text { Proveudtagr } \\
\text { Type }\end{array}$ & Dato & Formation & Dybde & Analyse & $\begin{array}{c}\mathrm{SO}_{\mathrm{e}}^{--} \\
\mathrm{mg} / \mathrm{I}\end{array}$ & 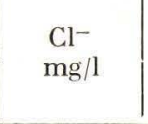 & $\substack{\mathrm{Br}-\\
\mathrm{m}_{3}-11}$ & 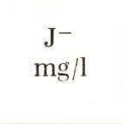 & 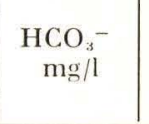 & 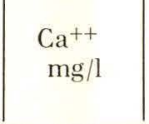 & 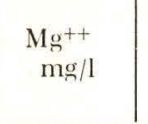 & $\underset{\substack{\mathrm{K}^{+} \\
\mathrm{mg} / 1}}{ }$ & $\begin{array}{c}\mathrm{Na}^{\mathrm{Na}} \\
\text { megs/ } \\
\text { mer. }\end{array}$ & 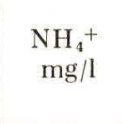 & 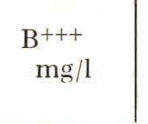 & $\mathrm{pH}$ & 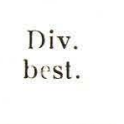 \\
\hline 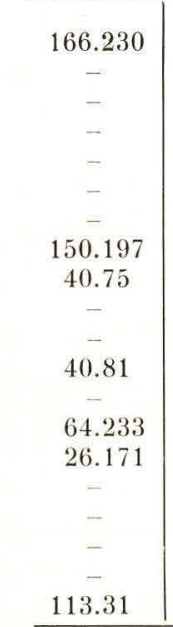 & 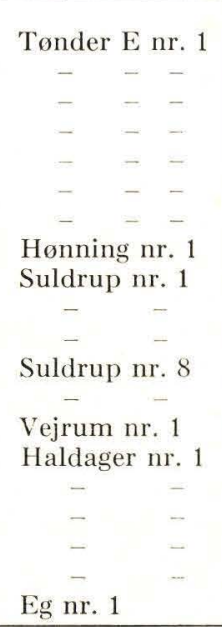 & 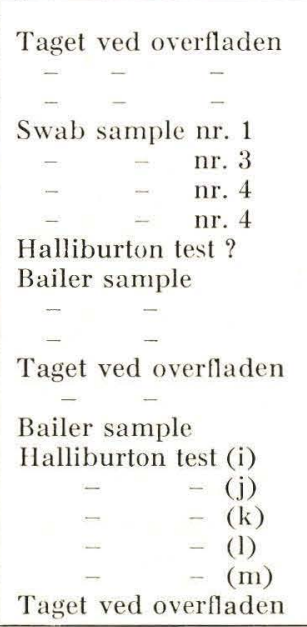 & 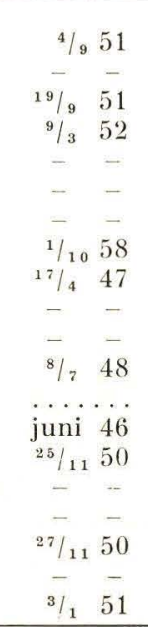 & 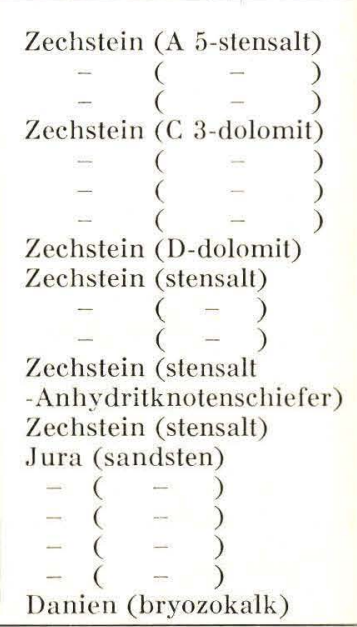 & 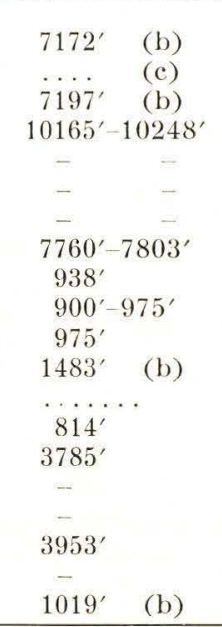 & 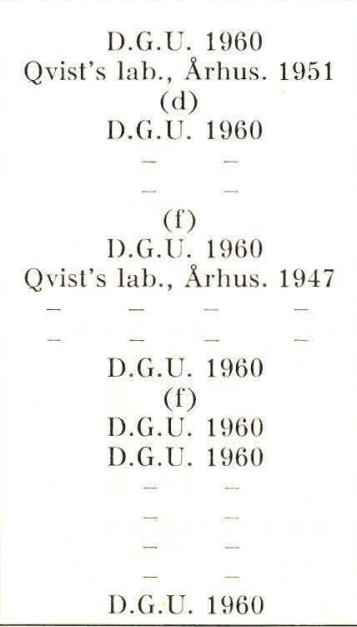 & 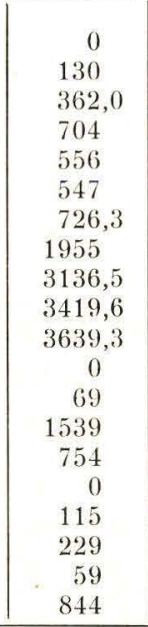 & 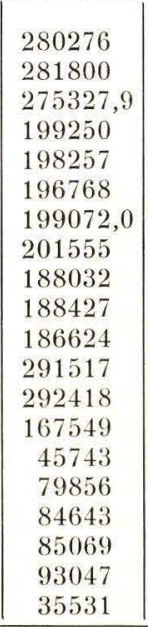 & 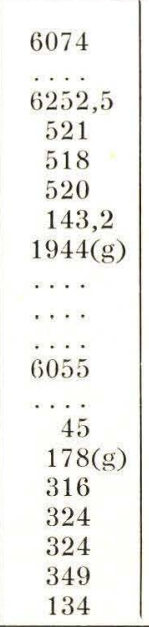 & 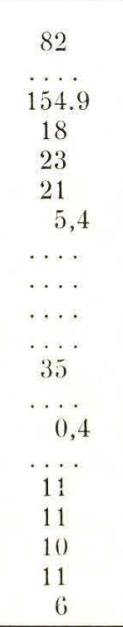 & 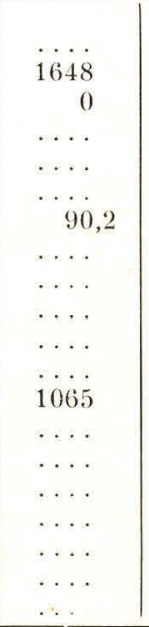 & 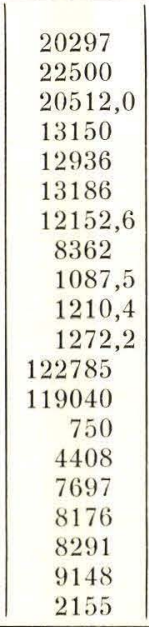 & 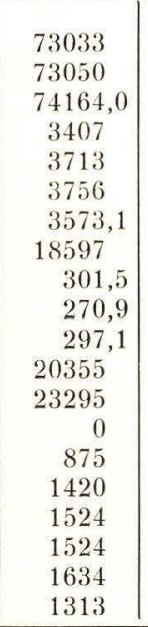 & 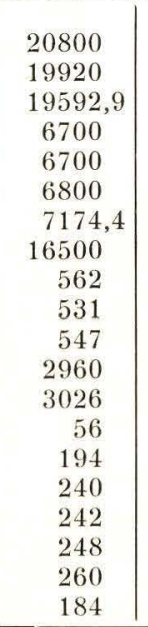 & 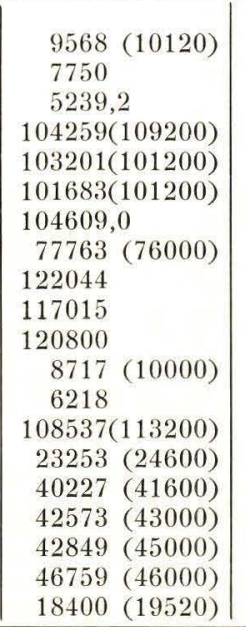 & $\begin{array}{c}240 \\
245 \\
\cdots \\
+ \\
88 \\
8 \\
\cdots \\
\cdots \\
63 \\
63 \\
\cdots \\
+ \\
+ \\
57 \\
+7 \\
16\end{array}$ & 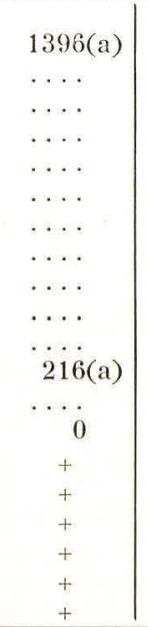 & 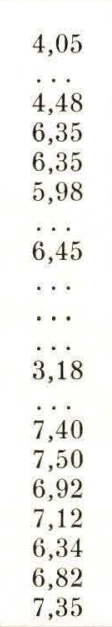 & $\begin{array}{c}\dddot{a}) \\
\dddot{(e)}) \\
\cdots\end{array}$ \\
\hline
\end{tabular}


Tavle II.

Stensalt - Rock Salt

Anhydritknotenschiefer - Anhydrite Knot Shale

Sandsten - Sandstone

Bryozokalk - Bryozoan Limestone

Skrivekridt - White Chalk

144 stands off bottom

237 - - -

$319--$

$458-7-$

530

1 stand $=2$ rørlœngder à 30'

+ Til stede - present

- $\mathrm{Br}^{-}+\mathrm{J}^{-}$beregnet som $\mathrm{Br}^{-}$

$\mathrm{Br}^{-}+\mathrm{J}^{-}$calculated as $\mathrm{Br}^{-}$

.. $\mathrm{Cl}^{-}+\mathrm{Br}^{-}+\mathrm{J}^{-}$beregnet som $\mathrm{Cl}^{-}$

$\mathrm{Cl}^{-}+\mathrm{Br}^{-}+\mathrm{J}^{-}$calculated as $\mathrm{Cl}^{-}$

... Analyse udfort af Qvist's laboratorium, Århus Analysis made by Ovist's laboratory, Árhus

.... Analyse efter RANKAMA,K. \& SAHAMA,TH., 1949

Analysis according to RANKAMA,K. \& SAHAMA,TH.,1949

Analyse efter ØDUM,H. \& CHRISTENSEN, WR., 1936

Analysis according to ØDUM,H. \& CHRISTENSEN, WR., 1936 
SALT

MINERAL WATER

ANALYSES

Arkiv n
File no.

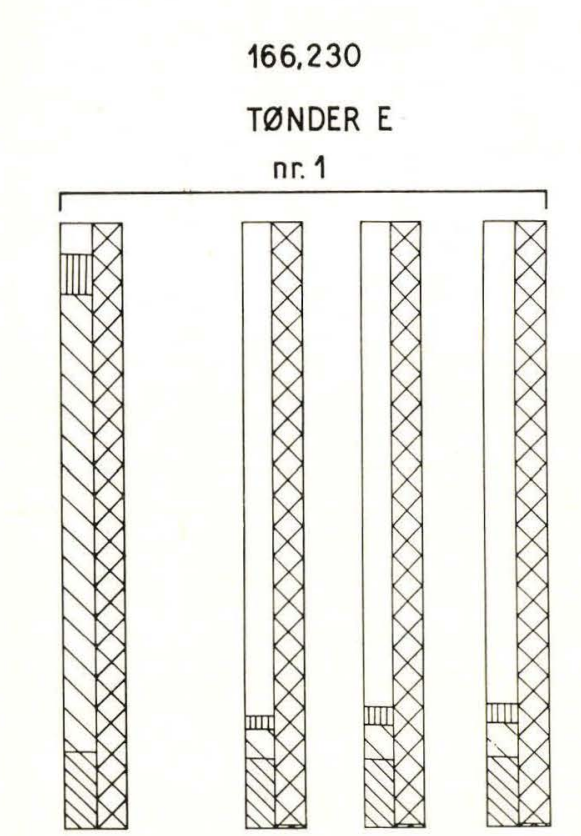

150,197

\begin{tabular}{c|ccc}
150,197 & 40,75 & 40,81 & 64,233 \\
HENNING & SULDRUP & SULDRUP & VEJRUM \\
nr. 1 & nr. 1 & nr. 8 & nr. 1
\end{tabular}

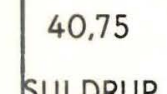

Ekviva

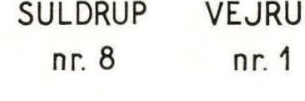

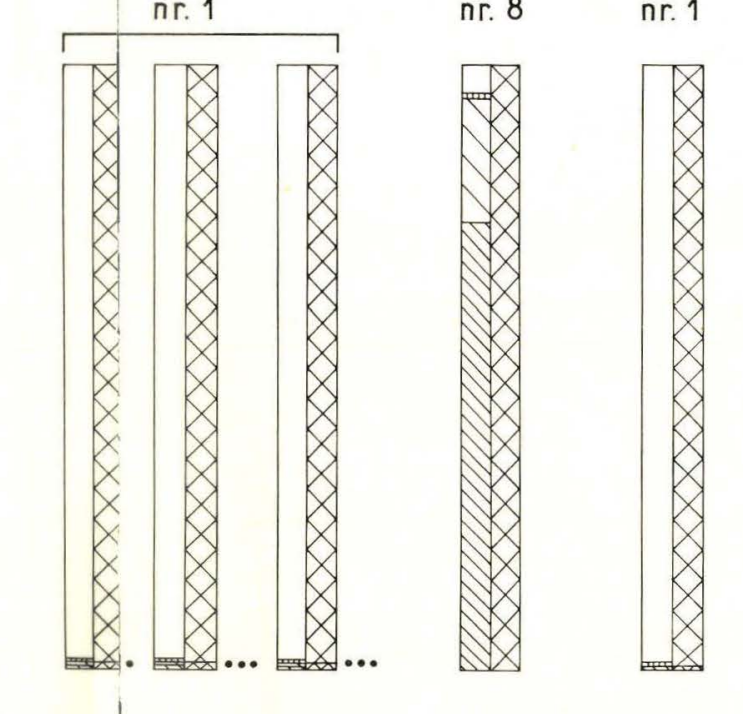

Formation
Formation

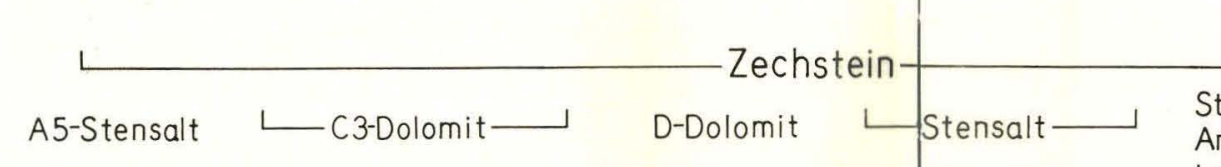

A5-Stensalt ᄂC3-Dolomit— D-Dolomit $\sqcup$ Stensalt $\longrightarrow$

Dybde
Depth
Ddtaget

Depth
Udtaget
Taken

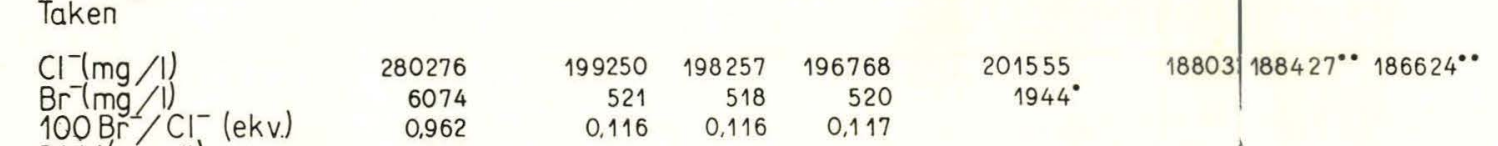

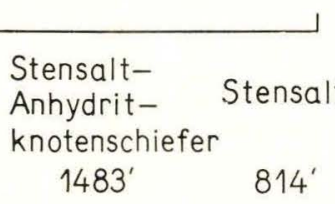

$\begin{array}{ll} & \text { Stensal } \\ 1483^{\prime} & 814^{\prime} \\ 1946 & 1946\end{array}$

$\begin{array}{cc}291117 & 167549 \\ 60.553 & 0.55 \\ 0.535 & 0.012 \\ 2016 \\ 633 & 0 \\ 3.18 & 0 \\ & 7.40 \\ & \end{array}$
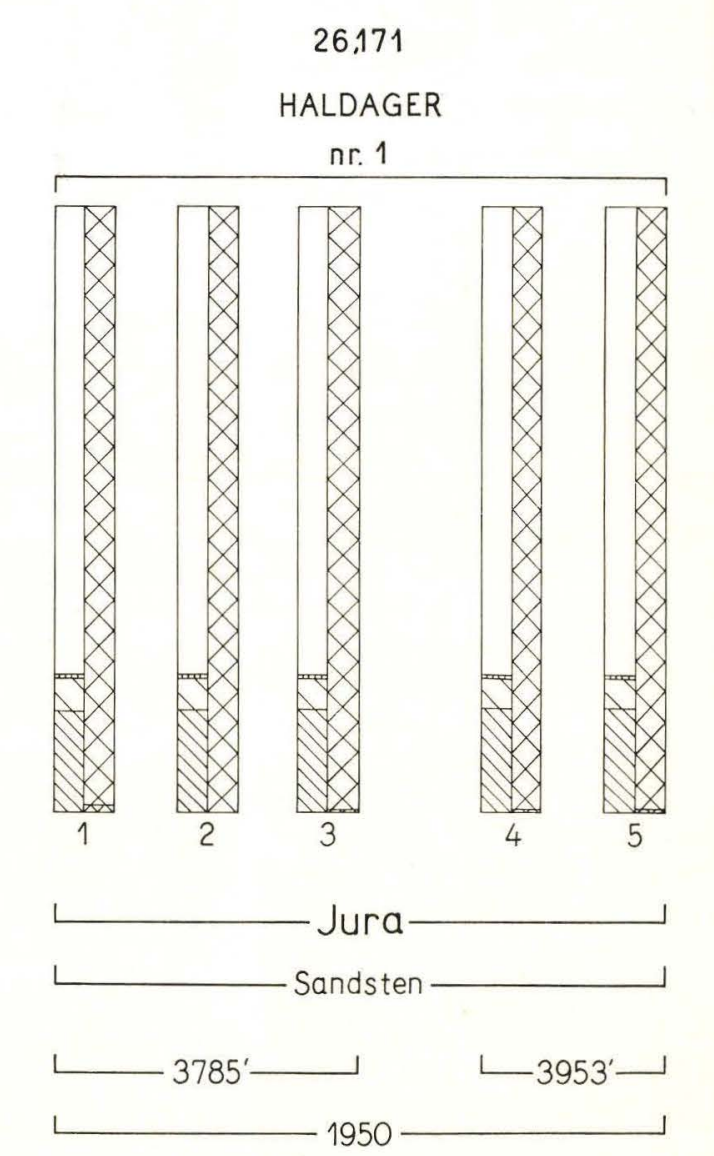

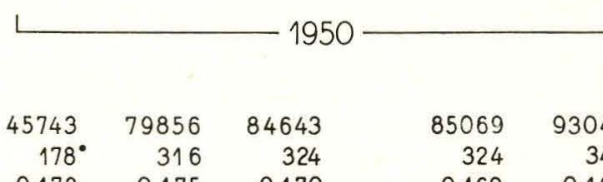

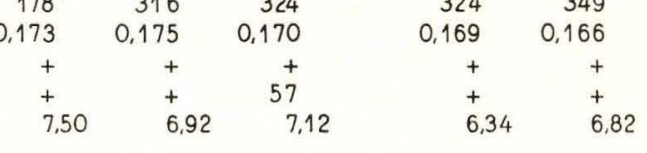

$\begin{array}{lllll}113,31 & 170,3 & 169,28 & 173,21 & 242,27\end{array}$

EG SøNDERBoRG LANGBRO TULLEBøLLE GEDSER
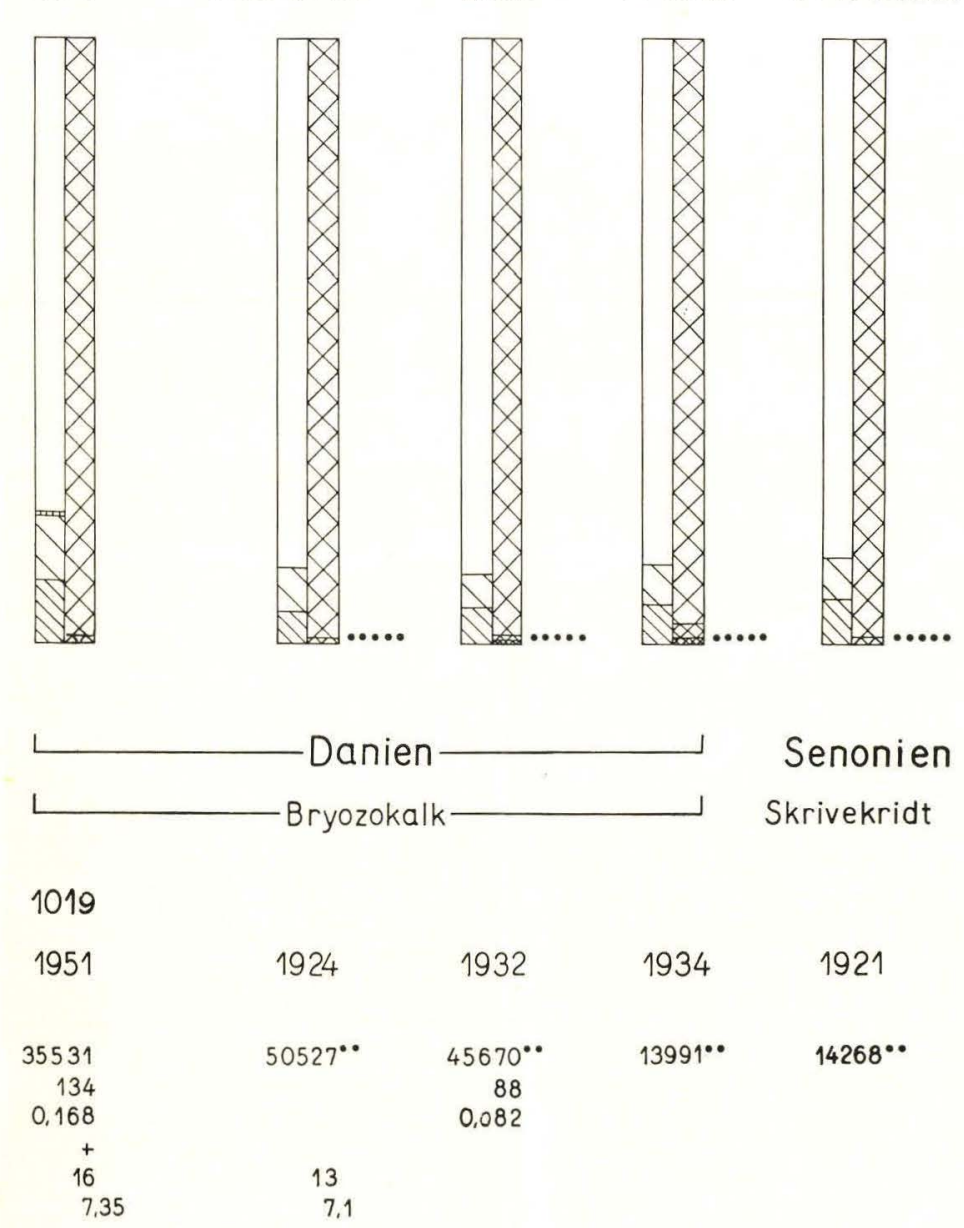

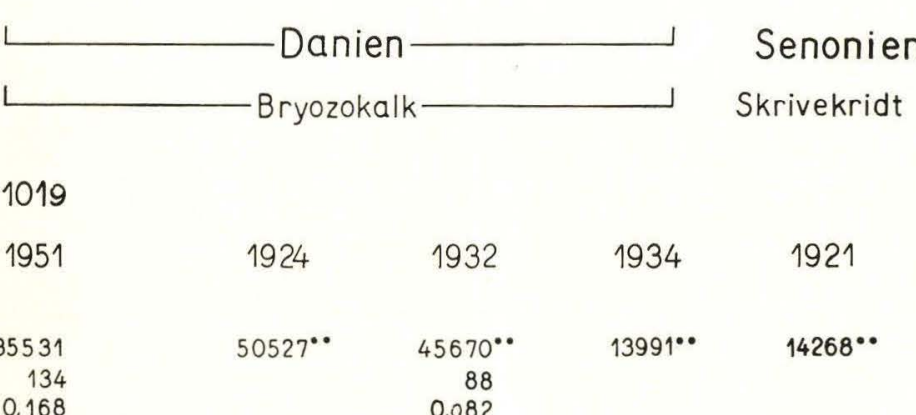

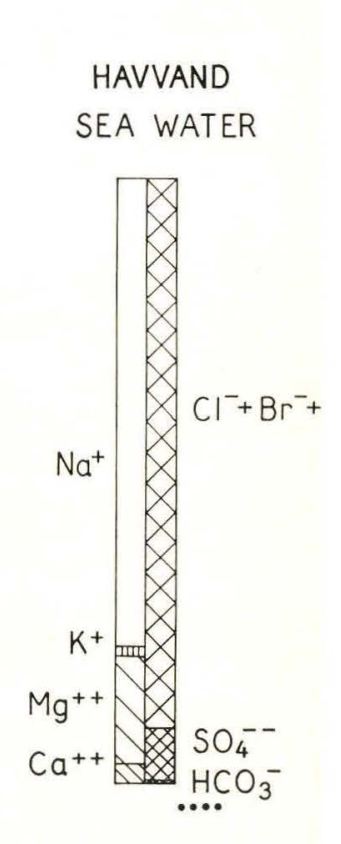

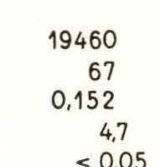

